\title{
PEMBATASAN HAK UNTUK MENIKAH ANTARA PEKERJA DALAM SATU PERUSAHAAN
}

\author{
Wurianalya Maria Novenanty \\ email: wurianalya_maria@yahoo.com
}

\begin{abstract}
There are a number of corporations or economic entities which enact internal employment regulations prohibiting its employees to inter-marry. Sanction to the violation of this rule is voluntary or forced resignation. It is argued that the ratio legis is to prevent personal conflict of interest, discriminative treatment and incidence of corruption-collusion and nepotism in the work place. The author shall critically analyze such regulation against the background of the prevailing laws, i.e. the 1945 Constitution, Human Rights laws, Marriage Law (1/1974) and Labor law (13/2003). The author's main finding is that it is permissible to restrict a person's right to marry under certain conditions, i.e. in the nation's interest and public order and that such limitation can only be applied by public corporations working in the public interest.
\end{abstract}

Keywords:

human rights, marriage, labor, corporations

\begin{abstract}
Abstrak
Saat ini ada beberapa perusahaan yang membuat aturan yang mengharuskan pekerjanya mengundurkan diri atau bahkan bersedia di-PHK apabila ia memutuskan menikah dengan pekerja lain di perusahaan tersebut. Alasannya, antara lain, mencegah konflik pribadi, subyektivitas, korupsi, kolusi, dan nepotisme. Penulis mengkaji kesesuaian aturan tersebut dengan peraturan perundang-undangan di Indonesia: Undang-Undang Dasar 1945, Peraturan yang terkait dengan Hak Asasi Manusia, Undang-Undang No. 1 Tahun 1974 tentang Perkawinan, dan Undang-Undang No. 13 Tahun 2003 tentang Ketenagakerjaan. Temuan utama penulis adalah bahwa hak untuk menikah sebenarnya dapat dibatasi asalkan untuk kepentingan bangsa dan ketertiban umum. Pembatasan hanya dapat diberlakukan oleh perusahaan yang bersifat publik dengan tujuan memajukan kepentingan publik.
\end{abstract}

Kata kunci:

hak asasi manusia, perkawinan, pekerja, perusahaan

\section{Pengantar}

Manusia dilahirkan ke dunia, kemudian ia menjadi subyek hukum. Subyek hukum adalah penyandang hak dan kewajiban. Salah satu hak yang ia sandang adalah hak untuk berkeluarga, di mana hak ini diatur pelaksanaannya oleh Undang-Undang. Hak berkeluarga ini merupakan salah satu hak asasi manusia yang diatur di dalam Pasal 28 B, ayat 1. Pasal ini menyatakan "Setiap orang berhak membentuk keluarga dan melanjutkan keturunan melalui perkawinan yang sah."

Di Indonesia, Undang-Undang yang mengatur mengenai Perkawinan adalah Undang-Undang No. 1 Tahun 1974 tentang Perkawinan, selanjutnya disebut 
sebagai Undang-Undang Perkawinan. Undang-Undang Perkawinan mengatur mengenai dasar dan syarat-syarat sahnya perkawinan bagi Warga Negara Indonesia. Dalam pasal 2, ayat 1, Undang-Undang tersebut dinyatakan bahwa perkawinan adalah sah, apabila dilakukan menurut hukum masing-masing agamanya dan kepercayaannya itu. Kemudian diatur lebih lanjut pada ayat 2, bahwa tiap-tiap perkawinan dicatat menurut peraturan perundang-undangan yang berlaku. ${ }^{1}$

Terkait perkawinan, saat ini beberapa perusahaan baik perusahaan pemerintah, maupun swasta, menetapkan suatu klausul yang membatasi hak untuk melangsungkan perkawinan antara sesama pekerja yang bekerja dalam perusahaan tersebut. Salah satu peraturan perundang-undangan yang mengatur pembatasan tersebut adalah pasal 153, huruf f, Undang-Undang No. 13 Tahun 2003 tentang Ketenagakerjaan. Pasal tersebut mengizinkan Pemutusan Hubungan Kerja dengan alasan adanya ikatan perkawinan antara sesama pekerja, sepanjang itu telah diatur dalam perjanjian kerja, peraturan perusahaan, atau perjanjian kerja bersama. ${ }^{2}$

Pembatasan tersebut artinya apabila antara pekerja melangsungkan pekawinan, maka salah satu dari mereka harus mundur dari perusahaan atau bahkan mendapat PHK berdasarkan perjanjian kerja, peraturan perusahaan, atau perjanjian kerja bersama. Hal ini tidak secara eksplisit dinyatakan sebagai larangan kawin, namun perusahaan dalam hal ini secara halus menghimbau pekerjanya untuk tidak bekerja satu atap dengan pasangan suami/istrinya. Adapun pertimbangan pemberlakuan aturan tersebut menurut Sri Muliati Abdullah antara lain: ${ }^{3}$

1. Mewujudkan pemerataan pendapatan di masyarakat. Aturan tersebut diharapkan bisa membuka peluang kerja yang lebih luas bagi keluarga-

1 Undang-Undang R.I., No. 1 Tahun 1974, Perkawinan, L.N.R.I. Tahun 1974 No. 1, Pasal 2 ayat 1

2 Undang-Undang R.I., No. 13 Tahun 2003, Ketenagakerjaan, L.N.R.I. Tahun 2003 No. 39, Pasal 153 huruf $\mathrm{f}$

3 Careernews, Pasutri Dilarang Sekantor, http//careernews.id/issues/view/2240-PasutriDilarang-Sekantor, 26 Februari 2016, 14.10. 
keluarga lainnya, sehingga kesejahteraan tidak hanya terpusat pada keluargakeluarga tertentu saja.

2. Menghindari konflik pribadi. Apabila pasangan suami istri bekerja di satu perusahaan yang sama, maka ada kekhawatiran urusan rumah tangga bisa terbawa ke kantor, begitupun sebaliknya. Hal semacam itu bisa berpengaruh pada kinerja pasangan tersebut di perusahaan.

3. Menghindari unsur subyektivitas dalam penerapan aturan di kantor. Apabila pasangan suami istri bekerja di perusahaan yang sama, maka dikhawatirkan pemberian reward dan punishment tidak akan maksimal. Hal ini dimungkinkan terjadi apabila salah satu dari pasangan tersebut memiliki jabatan yang lebih tinggi dan memiliki kewenangan untuk memberikan reward dan menjatuhkan punishment.

4. Menghindari Korupsi, Kolusi, dan Nepotisme. Ada risiko terciptanya korupsi, kolusi, dan nepotisme apabila ada hubungan kekeluargaan di dalam suatu kantor yang dilandasi motif memperkaya keluarga.

Permasalahan yang muncul adalah apakah pembatasan semacam tersebut diperkenankan oleh hukum di Indonesia? Sebagaimana penulis telah jelaskan di atas bahwa hak untuk berkeluarga adalah hak asasi manusia yang diatur dalam Undang-Undang Dasar 1945. Selain itu hak ini pun diatur dalam Undang-Undang No. 39 Tahun 1999 tentang Hak Asasi Manusia, selanjutnya disebut sebagai "Undang-Undang HAM". Kemudian, karena permasalahan ini menyangkut pekerja perlu dikaji pula kesesuaiannya berdasarkan Undang-Undang No. 13 Tahun 2013 tentang Ketenagakerjaan, selanjutnya disebut sebagai "Undang-Undang Ketenagakerjaan", serta Undang-Undang Perkawinan, karena pembatasan ini berhubungan dengan perkawinan. Di bagian akhir, pembatasan ini akan dikaji dalam satu sistem hukum Indonesia. 


\section{Pembatasan Hak Untuk Melangsungkan Perkawinan Antara Pekerja dalam Satu Perusahaan Berdasarkan Undang-Undang Dasar 1945}

Agar dapat mewujudkan martabat kemanusiaannya, Tuhan menganugerahkan manusia dengan hak-hak dasar atau hak-hak asasi. Tanpa hakhak tersebut, manusia dapat kehilangan martabat kemanusiaannya. Hak dasar dan kebebasan dasar yang melekat secara kodrati pada seorang manusia itulah yang disebut sebagai Hak Asasi Manusia. Mengingkari Hak Asasi Manusia ini berarti mengingkari pula martabat kemanusiaan. Menyadari betapa esensialnya Hak Asasi Manusia ini, maka Negara atau Organisasi wajib mengakui dan melindungi Hak Asasi Manusia tiap manusia, tanpa kecuali. ${ }^{4}$

Sebagai suatu negara, Indonesia mengakui dan melindungi Hak Asasi Manusia dalam Undang-Undang Dasar 1945. Perlindungan, pemajuan, penegakan, dan pemenuhan Hak Asasi Manusia merupakan tanggung jawab negara, khususnya pemerintah, di mana hal tersebut dilakukan sesuai dengan prinsip negara hukum yang demokratis. Oleh karena itu, pelaksanaannya harus dijamin dan diatur dalam peraturan perundang-undangan. ${ }^{5}$

Mengenai Hak Asasi Manusia dalam ranah perkawinan, diatur dalam Pasal 28B, ayat 1, UUD 1945, yang menyatakan "Setiap orang berhak membentuk keluarga dan melanjutkan keturunan melalui perkawinan yang sah." Sedangkan mengenai hak atas pekerjaan diatur dalam pasal 27, ayat 2, yang berbunyi: "Tiaptiap warga negara berhak atas pekerjaan dan penghidupan yang layak." Kemudian pasal 28D, ayat 2, menyatakan "Setiap orang berhak untuk bekerja serta mendapat imbalan dan perlakuan yang adil dan layak dalam hubungan kerja." Apabila ketiga pasal tersebut dikaitkan dengan permasalahan yang penulis angkat, maka dapat disimpulkan bahwa manusia memiliki hak asasi untuk berkeluarga dan bekerja. Apakah kedua hak tersebut dapat dibatasi? Pada dasarnya menurut pasal 28J, ayat 1, setiap orang wajib menghormati hak asasi manusia orang lain dalam tertib

4 B. Arief Sidharta, Konsepsi Hak Asasi Manusia, Nomor 4 Bulan Oktober Tahun XX Jurnal Hukum Pro Justitia, 2002, hlm., 13

5 Rhona K.M. Smith, Hukum Hak Asasi Manusia, Pusat Studi Hak Asasi Manusia UII (Pusham UII), Yogyakarta, 2008, hlm., 242. 
kehidupan bermasyarakat, berbangsa, dan bernegara. Walaupun demikian, ternyata hak asasi manusia dapat dibatasi. Pembatasan tersebut dapat ditemukan dalam Pasal 28 J ayat (2) yang berbunyi:

"Dalam menjalankan hak dan kebebasannya, setiap orang wajib tunduk kepada pembatasan yang ditetapkan dengan undang-undang dengan maksud semata-mata untuk menjamin pengakuan serta penghormatan atas hak dan kebebasan orang lain dan untuk memenuhi tuntutan yang adil sesuai dengan pertimbangan moral, nilai-nilai agama, keamanan, dan ketertiban umum dalam suatu masyarakat demokratis."

Jadi sebenarnya Undang-Undang Dasar 1945 membuka kesempatan untuk adanya pembatasan terhadap hak asasi manusia apabila hal tersebut guna menjamin pengakuan serta penghormatan atas hak dan kebebasan orang lain dan untuk memenuhi tuntutan yang adil sesuai dengan pertimbangan moral, nilai-nilai agama, keamanan, dan ketertiban umum dalam suatu masyarakat demokratis. Pembatasan tersebut ditetapkan dalam suatu undang-undang.

Ada beberapa hak asasi manusia yang tidak dapat disimpangi. Hal ini diatur dalam pasal 28 I Undang-Undang Dasar 1945. Adapun bunyi pasal tersebut adalah "Hak untuk hidup, hak untuk tidak disiksa, hak untuk kemerdekaan pikiran dan hati nurani, hak beragama, hak untuk tidak diperbudak, hak untuk diakui sebagai pribadi di hadapan hukum, dan hak untuk tidak dituntut atas dasar hukum yang berlaku surut adalah hak asasi manusia yang tidak dapat dikurangi dalam keadaan apapun." Jenis hak asasi manusia yang diatur dalam pasal 28B, Ayat 1, dan pasal 28D, Ayat 2 tidak termasuk ke dalam hak asasi manusia yang tidak dapat dikurangi dalam keadaan apapun, sehingga dapat ditafsirkan bahwa hak asasi manusia tersebut dapat dibatasi sebagaimana diatur dalam pasal 28J, UndangUndang Dasar 1945. Berkenaan dengan apakah pembatasan terhadap dua jenis hak asasi manusia tersebut terkait larangan kawin antara sesama pekerja dalam satu perusahaan, maka yang perlu ditelusuri lebih lanjut adalah Undang-Undang Perkawinan dan Undang-Undang Ketenagakerjaan. 


\section{Pembatasan Hak Untuk Melangsungkan Perkawinan Antara Pekerja Dalam}

\section{Satu Perusahaan Dalam Kerangka Hak Asasi Manusia.}

Hak asasi manusia wajib ditegakkan oleh suatu negara sebagai wujud penghargaan terhadap martabat kemanusiaan. Pasal 1, angka 1, Undang-Undang HAM mendefinisikan hak asasi manusia sebagai seperangkat hak yang melekat pada hakikat dan keberadaan manusia sebagai makhluk Tuhan Yang Maha Esa dan merupakan anugerahNya yang wajib dihormati, dijunjung tinggi dan dilindungi oleh negara, hukum, Pemerintah, dan setiap orang demi kehormatan serta perlindungan harkat dan martabat manusia. ${ }^{6}$ Terhadap hak ini, dapat diadakan pembatasan sesuai dengan pasal 73, yang menyatakan bahwa hak dan kebebasan yang diatur dalam Undang-Undang HAM hanya dapat dibatasi oleh dan berdasarkan undang-undang semata-mata untuk menjamin pengakuan dan penghormatan terhadap hak asasi manusia serta kebebasan dasar orang lain, kesusilaan, ketertiban umum, dan kepentingan bangsa. Para filsuf menyebut hak asasi ini sebagai prima facie rights, yaitu hak yang berlaku sampai dikalahkan oleh hak lain yang lebih kuat. ${ }^{7}$

Pasal 28B, ayat 1, Undang-Undang Dasar 1945, dituangkan kembali dalam Pasal 10 Undang-Undang HAM. Sedangkan mengenai hak atas kesejahteraan, termasuk diantaranya hak atas pekerjaan yang dinyatakan dalam pasal 38, ayat 1 , Undang-Undang HAM: "Setiap warga negara, sesuai dengan bakat, kecakapan, dan kemampuan berhak atas pekerjaan yang layak." Kemudian dalam ayat 2 diatur bahwa setiap orang berhak dengan bebas memilih pekerjaan yang disukainya dan berhak pula atas syarat-syarat ketenagakerjaan yang adil. ${ }^{8}$ Hal ini pun didukung oleh pasal 6, ayat 1, International Covenant On Economic, Social, and Cultural Rights (Kovenan Internasional Tentang Hak-Hak Ekonomi, Sosial, dan Budaya)

\footnotetext{
6 Undang-Undang No. 39 Tahun 1999, Hak Asasi Manusia, L.N.R.I. Tahun 1999 No. 165, Pasal 1 angka 1.

7 Yahya Ahmad Zein, Konsep Hak Asasi Manusia Dalam Islam, Mengungkap Korelasi Antara Islam dengan HAM, Volume I No. 1 Jurnal veritas et justitia, Juni 2015, hlm. 96.

${ }^{8}$ Supra no. 7 , pasal 38 ayat 1 dan 2 .
} 
yang telah diratifikasi oleh Undang-Undang Nomor 11 Tahun 2005 (untuk selanjutnya disebut sebagai "ICESCR"), yang berbunyi:9

"Negara Pihak dari Kovenan ini mengakui hak atas pekerjaan, termasuk hak setiap orang atas kesempatan untuk mencari nafkah melalui pekerjaan yang dipilih atau diterimanya secara bebas, dan akan mengambil langkah-langkah yang tepat guna melindungi hak ini."

Apabila pasal-pasal tersebut dikaitkan dengan aturan dalam suatu perusahaan yang mengharuskan salah satu dari pasangan pekerja yang telah menikah untuk keluar, bahkan dapat dilakukan Pemutusan Hubungan Kerja terhadap pekerja tersebut, maka ada pelanggaran terhadap pasal 38, ayat 2 , Undang-Undang HAM dan pasal 6, ayat 2, ICESCR, di mana kedua pasal tersebut pada intinya menyatakan bahwa setiap warga negara berhak dengan bebas memilih pekerjaan yang disukainya. Kebebasan memilih tersebut dibatasi atau bahkan dilanggar oleh suatu perusahaan yang menerapkan aturan "wajib untuk mengundurkan diri atau bersedia di-PHK apabila menikah dengan sesama pekerja”. Bagaimana apabila pekerja yang mengundurkan diri tersebut menyukai pekerjaannya saat ini, namun harus pindah karena ia memutuskan menikah dengan sesama pekerja yang bekerja di perusahaan tersebut?

Masalah lain yang dapat timbul adalah, pasangan pekerja tersebut akhirnya memutuskan untuk tidak jadi menikah guna bertahan di badan hukum tersebut. Apabila mereka sepakat untuk tidak jadi menikah, kemudian berpisah baik-baik, seharusnya tidak ada masalah, tetapi terbuka juga kemungkinan mereka memilih untuk tinggal bersama tanpa ikatan perkawinan guna menghindari aturan. Hal ini bertentangan dengan nilai-nilai yang dianut oleh bangsa Indonesia, yang masih menjunjung tinggi lembaga perkawinan.

Merujuk pada pasal 73, Undang-Undang HAM, bahwa pembatasan hak asasi manusia sebenarnya dimungkinkan dilakukan untuk kepentingan-

9 Undang-Undang No,11 Tahun 2005 Tentang Pengesahan International Covenant on Economic, Social, and Cultural Rights (Kovenan Internasional tentang Hak-Hak Ekonomi, Sosial, dan Budaya), L.N.R.I. Tahun 2005 Nomor 118, pada Pasal 6 Kovenan 
kepentingan yang disebutkan dalam pasal tersebut. ${ }^{10}$ Aturan yang membatasi hak untuk melangsungkan perkawinan antar sesama pekerja dalam satu perusahaan, sebenarnya melanggar hak asasi manusia sebagaimana diatur dalam pasal 10 dan pasal 38, Undang-Undang HAM. Pertanyaannya adalah apakah pembatasan HAM ini dilakukan untuk menjamin pengakuan dan penghormatan terhadap hak asasi manusia serta kebebasan dasar orang lain, kesusilaan, ketertiban umum, dan kepentingan bangsa sebagaimana disebutkan dalam pasal 73? Apabila melihat alasan-alasan mengapa aturan pembatasan hak untuk menikah itu ada, penekanannya lebih pada kepentingan perusahaan, bukan kepentingan manusianya. ${ }^{11}$ Pembatasan untuk menikah tersebut harus dapat dibuktikan merupakan jaminan atas pengakuan dan penghormatan terhadap hak asasi manusia dan kebebasan dasar orang lain, kesusilaan, ketertiban umum, dan kepentingan bangsa. Lebih lanjut, dalam pasal 74, Undang-Undang HAM dinyatakan bahwa tidak ada satu ketentuan pun dalam Undang-Undang tersebut boleh diartikan bahwa Pemerintah, partai, golongan, atau pihak manapun dibenarkan mengurangi, merusak, atau menghapuskan hak asasi manusia atau kebebasan dasar dalam Undang-Undang HAM.

\section{Pembatasan Hak Untuk Melangsungkan Perkawinan Antara Pekerja Dalam Satu Perusahaan Dikaji Berdasarkan Undang-Undang No. 13 Tahun 2003 Tentang Ketenagakerjaan}

Sebelum memasuki suatu perusahaan, maka calon pekerja terlebih dahulu diminta untuk menandatangani suatu Perjanjian Kerja. Berdasarkan Pasal 1 Angka 14 Undang-Undang Ketenagakerjaan, Perjanjian Kerja didefinisikan sebagai perjanjian antara pekerja/buruh dengan pengusaha atau pemberi kerja yang memuat syarat-syarat kerja, hak, dan kewajiban para pihak. Adapun unsur yang wajib ada dalam suatu perjanjian kerja adalah sebagai berikut: ${ }^{12}$

\footnotetext{
10 Id., Pasal 73.

11 Supra No. 6, hlm., 258.

12 F.X. Djulmialdji, Perjanjian Kerja, Sinar Grafika, Jakarta 2005, hlm., 7-10.
} 
1. Ada hubungan atasan-bawahan antara para pengusaha/pemberi kerja (atasan) dengan para buruh/pekerja sebagai bawahan;

2. Ada suatu pekerjaan yang dilakukan;

3. Ada upah/imbalan.

Merujuk pada ketentuan pasal 1, ayat 3, Undang-Undang Ketenagakerjaan, pekerja adalah setiap orang yang bekerja dengan menerima upah atau imbalan dalam bentuk lain. Sedangkan definisi pengusaha menurut pasal 1, ayat 4 , Undang-Undang Ketenagakerjaan adalah orang perseorangan, pengusaha, badan hukum atau badan-badan lainnya yang mempekerjakan pekerja dengan membayar upah atau imbalan dalam bentuk lain. ${ }^{13}$

Pemberi Kerja dan pekerja memiliki suatu hubungan hukum keperdataan, artinya bahwa para pihak sama-sama memiliki kedudukan perdata. Selain itu, para pihak terikat pula oleh suatu hukum otonom yaitu ketentuan-ketentuan yang dibuat oleh pengusaha dan buruh/pekerja. Di luar hukum otonom ini, ada hukum heteronom yang mengatur hubungan antara pihak-pihak tersebut. Hukum heteronom ini ditetapkan oleh pembentuk undang-undang. ${ }^{14}$

Peraturan Perusahaan merupakan salah satu contoh hukum otonom. Peraturan ini dibuat oleh perusahaan, tanpa melibatkan buruh. Adapun isi dari peraturan ini adalah syarat-syarat kerja dan tata tertib perusahaan yang tidak dimuat dalam perjanjian kerja. Oleh karena itu, terdapat hubungan yang erat antara perjanjian kerja dan peraturan perusahaan, bahkan ada yang menyebutkan bahwa peraturan perusahaan ini adalah pelengkap dari perjanjian kerja. Peraturan Perusahaan ini harus memuat substansi minimal:

a. Hak dan kewajiban pengusaha;

b. Hak dan kewajiban pekerja/buruh;

c. Syarat kerja;

d. Tata tertib perusahaan;

e. Jangka waktu berlakunya peraturan perusahaan.

13 Id. hlm. 9-11.

14 Id. 
Pengertian dari syarat kerja dalam suatu perusahaan adalah hak dan kewajiban pengusaha dan pekerja/buruh di luar pengaturan dalam undang-undang. ${ }^{15}$

Syarat-syarat kerja pun dapat diatur dalam suatu Perjanjian Kerja Bersama. Perjanjian Kerja Bersama adalah perjanjian yang merupakan hasil perundingan antara serikat pekerja/serikat buruh atau beberapa serikat pekerja/serikat buruh yang tercatat pada instansi yang bertanggung jawab di bidang ketenagakerjaan dengan pengusaha atau beberapa pengusaha atau perkumpulan pengusaha yang memuat syarat-syarat kerja, hak dan kewajiban para pihak. ${ }^{16}$ Ketentuan dalam perjanjian kerja bersama ini tidak boleh bertentangan dengan peraturan perundang-undangan yang berlaku, apabila isi perjanjian kerja bersama tersebut bertentangan dengan peraturan perundang-undangan yang berlaku maka ketentuan yang bertentangan tersebut batal demi hukum dan yang berlaku adalah ketentuan dalam peraturan perundang-undangan. ${ }^{17}$ Menurut FX. Djumialdji, fungsi dari Perjanjian Kerja Bersama ini adalah:18

1. "Memudahkan pekerja/buruh untuk membuat Perjanjian Kerja..."

2. "Sebagai jalan keluar atau way out dalam hal perundang-undangan ketenagakerjaan belum mengatur hal-hal yang baru atau menunjukkan kelemahan-kelemahan di bidang tertentu. Seperti diketahui bahwa perundang-undangan Ketenagakerjaan belum mengatur selengkapnya atau kalau sudah mengatur keseluruhan, ternyata terbelakang dari kemajuan masyarakat, dengan demikian perjanjian kerja bersama dapat melengkapi atau mengaturnya.

3. Sebagai sarana untuk menciptakan ketenangan kerja bagi pekerja/buruh demi kelangsungan usaha bagi perusahaan.

4. Merupakan partisipasi pekerja/buruh dalam penentuan atau pembuatan kebijaksanaan pengusaha dalam bidang ketenagakerjaan."

Berdasarkan pemaparan di atas, maka dapat disimpulkan bahwa perbedaan antara perjanjian kerja, peraturan perusahaan dan perjanjian kerja bersama adalah pada pihak yang membuatnya. Perjanjian kerja dibuat oleh

\footnotetext{
15 Id., hlm 62-63.

16 Definisi tersebut dapat ditemukan dalam Pasal 1 Angka 21 Undang-Undang Ketenagakerjaan jo. Pasal 1 ayat (2) Keputusan Menteri Pekerja dan Transmigrasi Nomor: KEP-48/MEN/IV/2004

${ }^{17}$ Undang-Undang R.I., No. 13 Tahun 2003, supra catatan No.3, pasal 124, ayat 2 dan 3.

18 Supra no. 12, hlm., 71-73.
} 
pekerja dan pengusaha, peraturan perusahaan dibuat oleh pihak pengusaha, sedangkan perjanjian kerja bersama dibuat oleh pengusaha dan para pekerja/buruh. Kemudian apabila dilihat kedudukannya, perjanjian kerja haruslah tunduk pada perjanjian kerja bersama, begitupun peraturan perusahaan tidak perlu ada apabila sudah ada perjanjian kerja bersama. ${ }^{19}$ Akan tetapi, terdapat persamaan di antaranya, yakni sama-sama mengatur mengenai hak dan kewajiban para pihak, serta syarat-syarat kerja. Di dalam syarat-syarat kerja inilah aturan yang membatasi hak untuk menikah antara pekerja biasanya diatur.

Aturan yang menyatakan bahwa apabila antara pekerja menikah dalam satu perusahaan, maka salah satu wajib keluar atau bahkan akan di-PHK dapat diatur dalam perjanjian kerja, peraturan perusahaan atau perjanjian kerja bersama. Hal tersebut dapat disimpulkan dari pasal 153, huruf f, Undang-Undang Ketenagakerjaan. Pasal 153 tersebut mengatur alasan-alasan yang dilarang oleh Undang-Undang perihal Pemutusan Hubungan Kerja (PHK) oleh Pengusaha, salah satunya adalah pengusaha dilarang melakukan PHK karena pekerja/buruh mempunyai pertalian darah dan/atau ikatan perkawinan dengan pekerja/buruh lain dalam satu perusahaan, kecuali diatur lain dalam perjanjian kerja, peraturan perusahaan, atau perjanjian kerja bersama. ${ }^{20}$ Jadi selama aturan tersebut ada dalam perjanjian kerja, peraturan perusahaan, atau perjanjian kerja bersama maka pekerja wajib tunduk pada aturan tersebut.

\section{Pembatasan Hak Untuk Melangsungkan Perkawinan Antara Pekerja Dalam Satu Perusahaan Berdasarkan Undang-Undang No. 1 Tahun 1974 tentang Perkawinan}

Sebagaimana telah dijelaskan di atas, bahwa hak untuk berkeluarga melalui suatu perkawinan yang sah merupakan hak asasi manusia. Pasal 1 UndangUndang Perkawinan mendefinisikan perkawinan sebagai ikatan lahir dan batin

\footnotetext{
${ }^{19}$ Supra no. 2, pasal 127 dan 129.

20 Abdul Khakim, Pengantar Hukum Ketenagakerjaan Indonesia, PT Citra Aditya Bakti, Bandung, 2007, hlm., 192.
} 
antara seorang pria dengan seorang wanita sebagai suami istri dengan tujuan membentuk keluarga (rumah tangga) yang bahagia dan kekal berdasarkan Ketuhanan yang Maha Esa. ${ }^{21}$ Di Indonesia, perkawinan yang sah adalah perkawinan yang dilakukan sesuai dengan hukum agama dan kepercayaan masing-masing mempelai dan dicatatkan berdasarkan Undang-Undang Administrasi Kependudukan.

Perkawinan dapat dicatatkan apabila memenuhi syarat-syarat perkawinan yang telah ditetapkan dalam Undang-Undang Perkawinan, antara lain:22

1. Perkawinan harus didasari oleh kata sepakat (pasal 6, ayat 1, Undang-Undang Perkawinan);

2. Perkawinan harus memperoleh izin dari orang tua, bagi seseorang yang umurnya belum mencapai 21 tahun (pasal 6, ayat 2, Undang-Undang Perkawinan);

3. Perkawinan dilakukan oleh seorang laki-laki yang berusia minimal 19 tahun, dan perempuan yang berusia 16 tahun (pasal 7, ayat 1, Undang-Undang Perkawinan). Kemudian dalam ayat 2 pasal yang sama diatur bahwa wajib ada dispensasi dari pengadilan bagi seseorang yang ingin melangsungkan perkawinan di bawah umur yang telah ditetapkan dalam ayat 1;

4. Perkawinan tidak dapat dilakukan oleh seseorang yang telah menikah, kecuali diperbolehkan oleh pasal 3 ayat 2, Pasal 4, dan pasal 5 Undang-Undang Perkawinan (pasal 9, Undang-Undang Perkawinan);

5. Perkawinan tidak diperbolehkan dengan orang yang sama untuk ketiga kalinya (pasal 10, Undang-Undang Perkawinan);

6. Perkawinan berikutnya bagi seorang janda baru diperbolehkan setelah melalui suatu waktu tunggu sebagaimana diatur dalam Peraturan Pemerintah (pasal 11, Undang-Undang Perkawinan);

\footnotetext{
21 Undang-Undang RI., No. 1 Tahun 1974, supra catatan No. 1, pada Pasal 1.

22 Supra No. 2, hlm., 57-59.
} 
7. Perkawinan wajib dilakukan berdasarkan tata cara yang diatur dalam peraturan perundang-undangan tersendiri (pasal 12, Undang-Undang Perkawinan).

Selain syarat-syarat di atas, perkawinan pun sah apabila perkawinan tersebut tidak melanggar larangan yang ditetapkan dalam Pasal 8, UndangUndang Perkawinan. Adapun bunyi dari pasal tersebut adalah sebagai berikut: ${ }^{23}$

"Perkawinan dilarang antara dua orang yang:

a. Berhubungan darah dalam garis lurus ke bawah ataupun ke atas;

b. Berhubungan darah dalam garis keturunan menyamping yaitu antara saudara, antara seorang dengan saudara neneknya;

c. Berhubungan semenda, yaitu mertua, anak tiri, menantu dan ibu/bapak tiri;

d. Berhubungan susuan, yaitu orang tua susuan, anak susuan, saudara susuan dan bibi/paman susuan;

e. Berhubungan saudara dengan isteri atau sebagai bibi atau kemenakan dari isteri, dalam hal seorang suami beristri lebih dari seorang;

f. Mempunyai hubungan yang oleh agamanya atau peraturan lain yang berlaku, dilarang kawin."

Sebagaimana dapat kita lihat di atas, dalam huruf $\mathrm{f}$ “...peraturan lain yang berlaku, dilarang kawin", apakah perjanjian kerja, peraturan perusahaan atau perjanjian kerja bersama termasuk ke dalamnya yang mengatur mengenai pembatasan hak untuk melangsungkan perkawinan?

Peraturan lain yang berlaku yang dimaksud dalam pasal 8, huruf f, UndangUndang Perkawinan dapat ditafsirkan sebagai suatu peraturan perundangundangan yang mengikat umum. Contohnya adalah Peraturan Pemerintah No. 45 Tahun 1990 tentang Perubahan atas Peraturan Pemerintah No. 10 Tahun 1983 tentang Izin Perkawinan dan Perceraian bagi Pegawai Negeri Sipil. Pasal 8, Peraturan Pemerintah tersebut menyebutkan: ${ }^{24}$

${ }^{23}$ Hilman Hadikusuma, Hukum Perkawinan Indonesia Menurut: Perundangan Hukum Adat Hukum Agama, CV Mandar Maju, Bandung, 2003, hlm., 62.

${ }^{24}$ Peraturan Pemerintah R.I., No.45 Tahun 1990, Perubahan atas Peraturan Pemerintah No.10 Tahun 1983 tentang Izin Perkawinan dan Perceraian bagi Pegawai Negeri Sipil, L.N.R.I Tahun 1990 No. 61. 
(1) “Pegawai Negeri Sipil pria yang akan beristri lebih dari seorang, wajib memperoleh izin lebih dahulu dari Pejabat.

(2) Pegawai Negeri Sipil wanita tidak diizinkan untuk menjadi istri kedua/ketiga/keempat.

(3) Permintaan izin sebagaimana dimaksud dalam ayat (1) diajukan secara tertulis.

(4) Dalam surat permintaan izin sebagaimana dimaksud dalam ayat (3), harus dicantumkan alasan yang lengkap yang mendasari permintaan izin untuk beristri lebih dari seorang."

Oleh karena itu, dapat disimpulkan bahwa Pegawai Negeri Sipil pria tidak diizinkan melakukan poligami, tanpa izin dari pejabat. Sedangkan Pegawai Negeri Sipil wanita tidak diizinkan untuk menikahi seorang pria yang sudah menikah. Ini adalah contoh larangan kawin yang diatur dalam peraturan lain yang dimaksud dalam Undang-Undang Perkawinan.

Penulis menyimpulkan bahwa suatu perusahaan yang mengharuskan pekerja untuk mundur atau bahkan di-PHK setelah melangsungkan perkawinan dengan sesama pekerja sebenarnya mengandung larangan terselubung. Ketentuan itu tidak melarang dengan tegas sesama pekerja untuk menikah, namun ketentuan tersebut bisa dibaca apabila pekerja ingin tetap bertahan di perusahaan tersebut jangan menikah dengan pekerja lain yang ada di perusahaan yang sama.

Perjanjian kerja, peraturan perusahaan, dan perjanjian kerja bersama merupakan perjanjian yang dibuat oleh pihak-pihak yang ada dalam suatu perusahaan untuk menimbulkan hubungan keperdataan di antara mereka. Hal ini berbeda dengan konsep peraturan yang diatur dalam pasal 8, Undang-Undang Perkawinan, yaitu peraturan perundang-undangan. Jadi pembatasan hak untuk menikah antara pekerja dalam satu perusahaan sebenarnya tidak diatur dalam Undang-Undang Perkawinan. Oleh karena itu akibat hukum berdasarkan UndangUndang Perkawinan ini pun tidak ada. Berbeda halnya dengan Undang-Undang Ketenagakerjaan yang mengatur bahwa apabila ada hubungan perkawinan antara pekerja, maka hal tersebut dapat berakibat pada adanya Pemutusan Hubungan Kerja (PHK), apabila mereka telah menandatangani perjanjian kerja dan 
perjanjian kerja bersama yang mengatur pembatasan hak untuk menikah tersebut.

\section{Pembatasan Hak Untuk Melangsungkan Perkawinan Antara Pekerja Dalam Satu Perusahaan Berdasarkan Sistem Hukum Indonesia}

Menurut Sudikno Mertokusumo, sistem merupakan tatanan atau kesatuan yang utuh yang terdiri dari bagian-bagian atau unsur-unsur yang saling berkaitan erat satu sama lain, atau dengan kata lain sistem hukum adalah suatu kumpulan unsur-unsur yang ada dalam interaksi satu sama lain yang merupakan satu kesatuan yang terorganisasi dan kerja sama ke arah tujuan kesatuan. Hukum adalah suatu sistem. Sistem hukum di sini terdiri dari peraturan, putusan, pengadilan, lembaga atau organisasi dan nilai-nilai, di mana keseluruhan unsurunsur tersebut merupakan suatu hal yang kompleks. ${ }^{25}$

Dalam suatu sistem, unsur-unsur atau bagian-bagiannya saling berinteraksi. Ketika unsur-unsur atau bagian-bagian tersebut berinteraksi, maka dimungkinkan terjadinya konflik. Apabila terjadi pertentangan atau konflik, maka sistem tidak akan membiarkannya berlarut-larut. Sistem akan menghadapi dan mengatasinya dengan konsisten. Adapun cara sistem dalam menyelesaikan suatu pertentangan adalah dengan menyediakan asas-asas hukum. Intinya adalah apabila ada suatu permasalahan dalam sistem, maka jawabannya pun ada dalam sistem itu sendiri. 26

Sehubungan dengan permasalahan yang muncul terkait pembatasan hak untuk melangsungkan perkawinan antara sesama pekerja dalam satu perusahaan, maka jawabannya pun harus dicari dalam sistem hukum Indonesia. Di atas penulis telah menjelaskan tinjauan terhadap larangan kawin tersebut berdasarkan peraturan perundang-undangan, namun antara satu peraturan dengan peraturan lain belum saling dikaji kesesuaiannya secara mendalam, di mana hal tersebut akan dituliskan dalam bagian ini.

\footnotetext{
25 Sudikno Mertokusumo, Penemuan Hukum, Liberty, Yogyakarta, 2000, hlm., 18-20.

26 Id., hlm., 25-26.
} 
Setelah mengkaji Undang-Undang Hak Asasi Manusia dan Undang-Undang Ketenagakerjaan, maka penulis menyimpulkan bahwa ada inkonsistensi antara Undang-Undang yang satu dengan yang lainnya terkait hak untuk berkeluarga antara sesama pekerja dalam satu perusahaan. Pasal 153f, Undang-Undang Ketenagakerjaan yang mengatur alasan-alasan yang dilarang oleh Undang-Undang perihal Pemutusan Hubungan Kerja (PHK) oleh Pengusaha, salah satunya adalah pengusaha dilarang melakukan PHK karena pekerja/buruh mempunyai pertalian darah dan/atau ikatan perkawinan dengan pekerja/buruh lain dalam satu perusahaan, kecuali diatur lain dalam perjanjian kerja, peraturan perusahaan, atau perjanjian kerja bersama. Setelah membaca pasal ini, apabila ditafsirkan secara argumentum a contrario, maka dapat kita simpulkan bahwa pembatasan hak untuk melangsungkan perkawinan tersebut diperkenankan oleh UndangUndang Ketenagakerjaan. Namun, bagaimana apabila pasal $153 \mathrm{f}$ tersebut dikaitkan dengan Undang-Undang Hak Asasi Manusia? Pasal-pasal dalam UndangUndang HAM yang relevan untuk dikaitkan dengan Pasal 153f tersebut adalah pasal 10, Undang-Undang Hak Asasi Manusia yang berbunyi: "Setiap orang berhak membentuk keluarga dan melanjutkan keturunan melalui perkawinan yang sah.” dan pasal 38, ayat 1, yang berbunyi: "Setiap warga negara, sesuai dengan bakat, kecakapan, dan kemampuan berhak atas pekerjaan yang layak.", serta ayat 2, yang mengatur bahwa setiap orang berhak dengan bebas memilih pekerjaan yang disukainya dan berhak pula atas syarat-syarat ketenagakerjaan yang adil. Lebih lanjut pasal yang dilanggar oleh pasal 153f, Undang-Undang Ketenagakerjaan adalah pasal 6, ICESCR yang berbunyi: "Negara Pihak dari Kovenan ini mengakui hak atas pekerjaan, termasuk hak setiap orang atas kesempatan untuk mencari nafkah melalui pekerjaan yang dipilih atau diterimanya secara bebas, dan akan mengambil langkah-langkah yang tepat guna melindungi hak ini." Mengingat pasal-pasal yang telah dipaparkan sebelumnya, maka dapat disimpulkan pasal 153f, Undang-Undang Ketenagakerjaan sebenarnya membatasi Hak Asasi Manusia 
untuk berkeluarga dan untuk memperoleh pekerjaan yang layak sesuai dengan bakat, kecakapan, dan kemampuan.

Apabila disandingkan, memang Undang-Undang Ketenagakerjaan dan Undang-Undang Hak Asasi Manusia berada pada posisi yang setara, namun tidak mengatur hal yang sama dan tidak secara tegas ada pertentangan di dalamnya, sehingga tidak dapat diterapkan asas hukum lex specialis derogat legi generali. Sebenarnya pasal 124, ayat 2 dan 3, Undang-Undang Ketenagakerjaan mengatur bahwa apabila isi perjanjian kerja bersama tersebut bertentangan dengan peraturan perundang-undangan yang berlaku maka ketentuan yang bertentangan tersebut batal demi hukum dan yang berlaku adalah ketentuan dalam peraturan perundang-undangan. Akan tetapi, isi dari pasal 124 tersebut tidak dapat berlaku apabila kita melakukan penafsiran sistematis dengan pasal 153f, karena pasal 153f, mengizinkan adanya PHK apabila terjalin adanya suatu hubungan perkawinan antara sesama pekerja.

Tentunya ketika kita mengkaji suatu undang-undang, haruslah juga kita kita tinjau berdasarkan norma hukum yang paling tinggi yaitu Undang-Undang Dasar 1945 yang mengatur mengenai Hak Asasi Manusia. Pembatasan hak untuk berkeluarga tersebut harus kita hubungkan dengan pasal 28B, ayat 1, yang menyatakan "Setiap orang berhak membentuk keluarga dan melanjutkan keturunan melalui perkawinan yang sah." Kemudian mengenai hak atas pekerjaan diatur dalam pasal 27, ayat 2, yang mengatur bahwa tiap-tiap warga negara berhak atas pekerjaan dan penghidupan yang layak. Hak ini diatur lebih lanjut dalam pasal 28D, ayat 2, yang menyatakan "Setiap orang berhak untuk bekerja serta mendapat imbalan dan perlakuan yang adil dan layak dalam hubungan kerja." Adapun pembatasan terhadap Hak Asasi Manusia ada dalam pasal 28J, ayat 2, semata-mata untuk menjamin pengakuan serta penghormatan atas hak dan kebebasan orang lain dan untuk memenuhi tuntutan yang adil sesuai dengan pertimbangan moral, nilai-nilai agama, keamanan, dan ketertiban umum dalam suatu masyarakat demokratis. Lebih lanjut, mengenai pembatasan ini pun diatur 
dalam pasal 73, Undang-Undang Hak Asasi Manusia yang berbunyi: "Hak dan kebebasan yang diatur dalam Undang-Undang ini hanya dapat dibatasi oleh dan berdasarkan undang-undang semata-mata untuk menjamin pengakuan dan penghormatan terhadap hak asasi manusia serta kebebasan dasar orang lain, kesusilaan, ketertiban umum, dan kepentingan bangsa."

Apakah apabila suami-istri bekerja di suatu perusahaan yang sama maka hal tersebut menciderai pengakuan dan penghormatan atas hak dan kebebasan orang lain? Salah satu alasan mengapa suami-istri tidak boleh bekerja dalam satu perusahaan adalah untuk memeratakan kesejahteraan, agar tidak terpusat dalam beberapa keluarga saja. Namun bagaimana apabila, setelah keluar dari perusahaan tersebut, suami/istri mencari kerja di tempat lain, bukankah itu mengambil kesempatan orang lain untuk mendapatkan pekerjaan juga? Kemudian dikaitkan dengan pembatasan Hak Asasi Manusia untuk memenuhi tuntutan yang adil sesuai dengan pertimbangan moral, nilai-nilai agama, keamanan, dan ketertiban umum, memunculkan pertanyaan apakah aturan pembatasan Hak Asasi untuk berkeluarga tersebut untuk memenuhi tuntutan yang adil? Belum tentu suami-istri yang bekerja dalam satu perusahaan itu pasti akan membawa dampak buruk bagi perusahaan tersebut, salah satunya adalah munculnya ketidakadilan. Kata-kata "belum tentu" di sini karena dikembalikan pada manusianya.

Ketika berbicara mengenai manusia, maka kita berbicara mengenai makhluk yang memiliki akal budi dan hati nurani. Nilai-nilai dalam kesadaran manusia terbentuk dari akal budi dan hati nurani tersebut. Dengan adanya nilainilai tersebut, manusia memiliki nilai-nilai dan kemampuan untuk memberikan penilaian perihal apa yang baik, buruk, salah, benar, adil, tidak adil, manusiawi, tidak manusiawi, bermoral, tidak bermoral. Nilai-nilai dalam kesadaran manusia tersebut yang akan membawa ketertiban dalam masyarakat. ${ }^{27}$ Oleh karena itu, dapat disimpulkan bahwa ketertiban dalam masyarakat, terwujud karena manusia

27 B. Arief Sidharta, Ilmu Hukum Indonesia Upaya Pengembangan Ilmu Hukum Sistematik yang Responsif terhadap Perubahan Masyarakat, Unpar Press, Bandung, 2016, hlm., 1-2. 
yang memiliki kesadaran akan nilai yang baik dan benar. Walaupun demikian, tidak dapat dipungkiri bahwa ada manusia yang harus diarahkan untuk memiliki kesadaran semacam itu, salah satunya adalah melalui norma hukum yang memaksa masyarakat untuk melakukan suatu perilaku demi terciptanya ketertiban berkeadilan. ${ }^{28}$

Menurut Roscoe Pound, tugas hukum yang mengarahkan dan membangun suatu struktur masyarakat, diistilahkan dengan "engineering". Adapun tujuan dari "engineering" tersebut adalah untuk mencapai kepuasan secara maksimum dan meminimalisir konflik dan pemborosan. Lebih lanjut, untuk mendukung pendapatnya tersebut, Pound membagi kepentingan-kepentingan yang dilindungi oleh hukum ke dalam 3 bagian:29

"Ke dalam kepentingan umum termasuk:

(1) Kepentingan terhadap negara sebagai suatu badan yuridis;

(2) Kepentingan terhadap negara sebagai penjaga dari kepentingan sosial.

Kepentingan perorangan terdiri dari:

(1) Pribadi (fisik, kebebasan kemauan, kehormatan, privacy dan kepercayaan serta pendapat);

(2) Hubungan-hubungan domestik (orang tua, anak, suami-istri);

(3) Kepentingan substansi (milik, kontrak dan berusaha, keuntungan, pekerjaan, hubungan dengan orang lain).

Kepentingan sosial meliputi:

(1) Keamanan umum;

(2) Keamanan dari perusahaan-perusahaan sosial;

(3) Moral umum;

(4) Pengamanan sumber-sumber daya sosial;

(5) Kemajuan sosial dan

(6) Kehidupan individual (pernyataan diri, kesempatan dan kondisi kehidupan."

Kepentingan-kepentingan yang telah diuraikan di atas kadang dalam aturan maupun dalam pelaksanaannya mengalami benturan. Pertanyaannya, kepentingan mana yang didahulukan? Apalagi dengan adanya kaidah-kaidah yang

\footnotetext{
28 Id., hlm., 12-13.

29 Satjipto Rahardjo, Ilmu Hukum, PT Citra Aditya Bakti, Bandung, 2012, hlm. 336.
} 
wajib diusahakan optimal dalam perwujudannya. Perintah optimalisasi suatu kaidah dapat bertentangan dengan perintah optimalisasi kaidah lain. Apabila terjadi permasalahan yang demikian, maka yang harus dilakukan adalah menimbang kepentingan-kepentingan (belangenafweging). Mengapa kepentingan yang harus ditimbang? Mengingat bahwa di balik suatu kaidah ada asas, di balik asas tersebut ada kepentingan. ${ }^{30}$

Kepentingan ini pun ada pada pasal 28I, Undang-Undang Dasar 1945 dan pasal 73 Undang-Undang Hak Asasi Manusia. Pembatasan Hak Asasi Manusia dapat dilakukan asalkan demi menjamin Hak Asasi Manusia dan kebebasan dasar orang lain, ketertiban umum, dan kepentingan bangsa. Menyangkut Hak untuk menikah antara sesama pekerja dalam satu perusahaan, ukurannya adalah apakah pernikahan tersebut dapat menciderai hak asasi manusia dan kebebasan dasar orang lain, ketertiban umum, dan kepentingan bangsa?

Sebenarnya apabila kita merujuk pada tataran ideal di mana setiap manusia memilki moral dan etika yang baik, tidak perlu ada pembatasan hak asasi manusia. Moral atau budi nurani merupakan suatu kaidah yang timbul dari dalam diri manusia dalam bentuk nilai-nilai kemanusiaan yang menjadi ukuran baik dan buruk tentang sikap dan perilaku manusia. Kemudian, moral atau budi nurani ini dapat bersifat obyektif dalam suatu komunitas atau masyarakat yang menimbulkan kaidah moral positif. ${ }^{31}$ Selanjutnya, mengenai etika, yang didefinisikan oleh R. Wayne Mondy sebagai suatu disiplin yang berkaitan dengan apa yang baik dan buruk, yang benar atau yang salah, atau dengan kewajiban dan tanggung jawab moral. ${ }^{32}$ Kesimpulan bahwa semua manusia memiliki moral dan etika yang baik merupakan kesimpulan yang utopis. Oleh karena itu, muncullah kaidah hukum.

30 Carel Smith (diterjemahkan oleh B. Arief Sidharta), Karakter Normatif Ilmu Hukum: Hukum sebagai Penilaian, Fakultas Hukum Universitas Katolik Parahyangan, Bandung, 2010, hlm., 1920.

31 Supra No. 24, hlm., 5-6.

32 R. Wayne Mondy, Manajemen Sumber Daya Manusia, Erlangga, Jakarta, 2008, hlm., 30. 
Alasan-alasan di balik suami-istri sebaiknya tidak sekantor adalah untuk membuka lapangan pekerjaan bagi keluarga lainnya, menghindari konflik pribadi dan subyektivitas, serta menghindari korupsi, kolusi, dan nepotisme (KKN). ${ }^{33}$ Alasan membuka lapangan pekerjaan bagi keluarga lainnya adalah untuk menjamin pelaksanaan hak asasi manusia keluarga lain, namun sebagaimana penulis telah jelaskan sebelumnya, hal ini belumlah dapat dipastikan pemenuhannya karena ada kemungkinan suami/istri yang keluar dari perusahaan mencari pekerjaan di tempat lainnya, yang artinya menutup kesempatan bagi keluarga lainnya untuk mendapatkan pekerjaan di tempat yang sama. Alasan untuk mencegah konflik pribadi, subjektivitas, dan KKN sebenarnya kembali pada manusianya, sebagaimana telah penulis jelaskan di atas bahwa apabila manusia memiliki akhlak dan moral yang baik maka masalah-masalah tersebut tidak akan muncul. Namun, tidak semua manusia memiliki akhlak dan moral yang baik, oleh karena itu hukum diperlukan untuk mengarahkan. Arahan itu jelas ada dalam pasal 28I, Undang-Undang Dasar 1945, pasal 73, Undang-Undang Hak Asasi Manusia, dan pasal 153, huruf f, Undang-Undang Ketenegakerjaan. Walaupun demikian, apakah memang Kaidah Hukum yang bisa menjawab permasalahan etika dan moral? Kenneth D. Lewis mengungkapkan pendapat sebagai berikut: ${ }^{34}$

"Ada perbedaan antara apa yang legal dan apa yang etis. Namun kita tidak sering membicarakannya, dan saya heran mengapa. Mungkin orang menganggapnya terlalu remeh...terlalu sulit didefinisikan...atau dalam bahasa perusahaan, tidak 'dapat diwujudkan.' Mungkin lebih mudah bagi kita untuk menyimak kembali undang-undang dan peraturan-peraturan baru sebagai solusinya. Namun undang-undang baru hanya bagian dari solusi. Dalam pandangan saya, mereka tidak menyentuh inti permasalahannya. Harus ada pemimpin yang mampu dan bersedia menanamkan etika ke seluruh budaya organisasi."

Dapat disimpulkan bahwa undang-undang memang bagian dari solusi, namun bukan sebagai satu-satunya solusi, karena adanya undang-undang tanpa disertai

\footnotetext{
33 careernews.id/issues/view/2240-Pasutri-Dilarang-Sekantor, 26 Februari 2016, 14:10.

34 Supra no. 32, hlm., 31.
} 
kesadaran hukum untuk melaksanakan isi undang-undang tersebut, maka ketidaktertiban dan ketidakadilan tetap dapat terjadi.

Untuk mewujudkan ketertiban yang berkeadilan tentunya dibutuhkan upaya, salah satunya adalah melalui peraturan perundang-undangan. Demi menjamin hak asasi manusia dan kebebasan dasarnya, ketertiban umum, dan kepentingan bangsa, maka beberapa hak memang sebaiknya dibatasi apabila implementasi hak tersebut dapat menciderai hak asasi manusia dan kebebasan dasar orang lain, menimbulkan ketidaktertiban, dan mengorbankan kepentingan bangsa. Salah satunya adalah hak untuk berkeluarga. Undang-Undang Perkawinan mengatur syarat-syarat perkawinan yang merupakan pembatasan hak untuk berkeluarga, salah satunya adalah pembatasan usia. Kemudian ada laranganlarangan menikah yang mencegah terjadinya perkawinan yang bertentangan dengan kesusilaan, hukum agama, dan peraturan-peraturan lainnya.

Perkawinan antara dua pekerja dalam satu perusahaan pun dapat dibatasi, namun dalam hal ini penulis membatasi pada perusahaan yang bersifat publik, bukan privat karena berbicara mengenai ketertiban umum dan kepentingan bangsa, maka kita bicara tentang suatu perusahaan yang diadakan oleh suatu kekuasaan umum yang pada pelaksanaan hak dan kewajibannya harus mengakomodir kepentingan umum. Ada pengalaman sejarah bahwa bangsa Indonesia pernah mengalami suatu masa di mana KKN merajalela di Indonesia yang pada akhirnya merugikan kepentingan bangsa dan negara.

Merujuk pada daftar kepentingan yang dibuat oleh Pound, maka yang harus diutamakan adalah kepentingan umum. Oleh karena itu pembatasan suatu hak asasi manusia harus melihat pada kepentingan tersebut. Suami-istri yang bekerja di dalam satu perusahaan memiliki dampak negatif, salah satunya adalah dapat terciptanya budaya kolusi, korupsi, nepotisme. Suatu badan hukum, khususnya badan hukum atau perusahaan publik harus menghindari hal-hal tersebut. Salah satu upaya untuk mencapai tujuan tersebut adalah dengan membuat aturan yang membatasi sesama pekerja untuk menikah, batasan di sini 
maksudnya adalah salah satu harus mengundurkan diri atau di-PHK, di mana hal ini diizinkan oleh pasal 153, huruf f, Undang-Undang Ketenagakerjaan selama hal tersebut sudah diatur di dalam Perjanjian Kerja atau Peraturan Perusahaan atau Perjanjian Kerja Bersama.

Bagaimana dengan perusahaan yang bersifat privat? Sebagaimana telah dijelaskan di atas bahwa tujuan perusahaan yang bersifat privat adalah kepentingan perorangan, maka tujuan pembatasan Hak Asasi Manusia dalam perusahaan tersebut adalah untuk kepentingan perusahaan itu semata. Seharusnya perusahaan yang bersifat privat menggunakan upaya-upaya lain yang tidak membatasi hak asasi manusia pekerjanya. Salah satu cara yang dapat digunakan adalah dengan melakukan manajemen Sumber Daya Manusia yang baik melalui teori-teori manajemen, di mana yang menjadi fokus dari teori-teori tersebut adalah pengaturan peranan manusia demi mencapai tujuan yang optimal. Hal ini perlu dilakukan karena tidak dapat dipungkiri ada kerumitan dalam mengatur pekerja yang memiliki rasio, rasa, status, kehendak, dan latar belakang yang berbeda-beda. ${ }^{35}$ Selain itu salah satu upaya yang digunakan untuk mencapai tujuan suatu perusahaan adalah penerapan prinsip Good Corporate Governance. Prinsip Good Corporate Governance adalah "seperangkat aturan yang mengatur hubungan antara pemegang saham, pengurus (pengelola) perusahaan, pihak kreditur, pemerintah, karyawan, serta pemegang kepentingan internal dan eksternal lainnya yang berkaitan dengan hak-hak dan kewajiban mereka atau dengan kata lain suatu sistem yang mengendalikan perusahaan." ${ }^{36}$ Prinsip-prinsip GCG ini terdiri dari transparansi, akuntabilitas, responsibiltas, independensi, kesetaraan, dan kewajaran. ${ }^{37}$ Intinya adalah masalah manajerial suatu perusahaan

\footnotetext{
35 Suwatno dan Donni Juni Priansa, Manajemen SDM dalam Organisasi Publik dan Bisnis, Alfabeta, Bandung, 2014, hlm., 16.

36 Lukas William Andypratama dan Ronny H. Mustamu, Penerapan Prinsip-Prinsip Good Corporate Governance pada Perusahaan Keluarga: Studi Deskriptif pada Distributor Makanan, Volume 1 Nomor 1 Jurnal Mahasiswa Manajemen Bisnis Agora (2013) http://id. portalgaruda.org/? $\underline{\text { ref=browse } \& \text { mod=viewarticle \&article=193721, diakses tanggal } 18 \text { Maret 2016, pukul } 16.44}$ 37 Id.
} 
baik yang bersifat publik maupun privat haruslah diselesaikan dengan solusi manajerial juga.

\section{Penutup}

Pembatasan hak untuk berkeluarga dan hak atas pekerjaan tidak perlu dilakukan apabila setiap individu yang bekerja dalam suatu perusahaan memiliki moral dan etika yang baik. Untuk itu, diperlukan adanya individu-individu yang menanamkan etika yang baik tersebut. Sedangkan, moral melekat pada masingmasing individu. Akan tetapi, apabila berharap bahwa semua orang memiliki moral dan etika yang baik, maka yang kita temukan adalah harapan kosong semata. Oleh karena itu, diciptakanlah ketentuan-ketentuan dalam norma hukum yang dapat mengarahkan moral dan etika tersebut untuk mencapai tujuan hukum. Dalam masalah yang penulis bahas, pembatasan itu ada dalam pasal 28I, UUD 1945, pasal 73, Undang-Undang HAM, dan pasal 153, huruf f, Undang-Undang Ketenagakerjaan.

Apakah hak untuk berkeluarga dapat dibatasi dan hak atas pekerjaan dapat dibatasi? ${ }^{38}$ Kepentingan yang harus diutamakan di sini adalah kepentingan umum dan ketertiban umum. Oleh karena itu pembatasan hak asasi manusia, salah satunya adalah hak untuk berkeluarga wajib dilakukan untuk tujuan-tujuan tersebut sehingga pembatasan lebih tepat dilakukan dalam suatu perusahaan yang bersifat publik, di mana adanya ikatan perkawinan dalam perusahaan tersebut rentan terhadap terjadinya korupsi dan nepotisme. Namun, untuk perusahaan yang sifatnya privat, pembatasan tersebut tidak tepat untuk diterapkan karena tujuan dari perusahaan tersebut lebih berat pada kepentingan perusahaan. Oleh karena itu pencegahan atas hal-hal yang bersifat manajerial, seharusnya ditangani dengan teori-teori manajemen, bukan dengan membatasi hak asasi manusia pekerja.

\footnotetext{
${ }^{38}$ Supra no. 27.
} 


\section{Daftar Pustaka}

\section{Buku:}

Abdul Khakim. Pengantar Hukum Ketenagakerjaan Indonesia, Bandung, PT Citra Aditya Bakti, Bandung, 2007.

B. Arief Sidharta, Ilmu Hukum Indonesia Upaya Pengembangan Ilmu Hukum Sistematik yang Responsif terhadap Perubahan Masyarakat, Unpar Press, Bandung, 2016.

Carel Smith, diterjemahkan oleh B.Arief Sidharta, Karakter Normatif Ilmu Hukum: Hukum sebagai Penilaian, Fakultas Hukum Universitas Katolik Parahyangan, Bandung, 2010.

Djaja S. Meliala, Perkembangan Hukum Perdata Tentang Orang dan Keluarga, Nuansa Aulia, Bandung, 2015.

F.X. Djulmialdji, Perjanjian Kerja, Jakarta, Sinar Grafika, Jakarta, 2005.

Hilman Hadikusuma, Hukum Perkawinan Indonesia Menurut Perundangan Hukum Adat Hukum Agama, Bandung, CV Mandar Maju, 2003.

Rhona K.M. Smith, Hukum Hak Asasi Manusia, Pusat Studi Hak Asasi Manusia UII (Pusham UII), Yogyakarta 2008.

R. Wayne Mondy, Manajemen Sumber Daya Manusia, Jakarta, Erlangga, Jakarta, 2008.

Satjipto Rahardjo, Ilmu Hukum, PT. Citra Aditya Bakti, Bandung, 2012.

Sudikno Mertokusumo, Penemuan Hukum, Liberty, Yogyakarta, 2000.

Suwatno dan Donni Juni Priansa, Manajemen SDM dalam Organisasi Publik dan Bisnis, Alfabeta, Bandung, 2014.

\section{Jurnal:}

Lukas William Andypratama dan Ronny H. Mustamu, Penerapan Prinsip-Prinsip Good Corporate Governance pada Perusahaan Keluarga: Studi Deskriptif pada Distributor Makanan, Jurnal elektronik Mahasiswa Manajemen Bisnis Agora Volume 1 Nomor 1, 2013, dengan website: http://id.portalgaruda. org/?ref=browse\&mod=viewarticle\&article=193721, 18 Maret 2016, 16:44.

B. Arief Sidharta, Konsepsi Hak Asasi Manusia, Jurnal Hukum Pro Justitia Tahun XX Nomor 4, Oktober 2002.

Yahya Ahmad Zein, Konsep Hak Asasi Manusia Dalam Islam, Mengungkap Korelasi antara Islam dengan HAM, Jurnal Veritas et Justitia, Volume I No. 1, Juni 2015.

\section{Internet:}

Careernews, Pasutri Dilarang Sekantor, http//careernews.id/issues/view/2240-Pasutri-Dilarang-Sekantor, 26 Februari 2016, 14:10. 


\section{Peraturan Perundang-Undangan:}

Undang-Undang Dasar Republik Indonesia Tahun 1945 dan Amandemen Indonesia, Undang-Undang Tentang Perkawinan, UU Nomor 1 Tahun 1974, Perkawinan, Lembaran Negara R.I No.1 Tahun 1974

Undang-Undang Tentang Hak Asasi Manusia, UU Nomor No. 39 Tahun 1999, Lembaran.Negara.R.I No.165 Tahun 1999

, Undang-Undang Tentang Ketenagakerjaan, UU Nomor 13 Tahun 2003, Lembaran Negara R.I. No. 39 Tahun 2003

Undang-Undang Tentang Pengesahan International Covenant on Economic, Social, and Cultural Rights (Kovenan Internasional tentang Hak-Hak Ekonomi, Sosial, dan Budaya), UU No. 11 Tahun 2005, Lembaran Negara R.I. No. 118 Tahun 2005

Peraturan Pemerintah Tentang Perubahan atas Peraturan Pemerintah No. 10 Tahun 1983 tentang Izin Perkawinan dan Perceraian bagi Pegawai Negeri Sipil Lembaran Negara R.I. No. 61 Tahun 1990 